\title{
MEMBANGUN MODEL PELAYANAN PUBLIK DESA: MENDEKATKAN PELAYANAN MASYARAKAT DI TINGKAT LOKAL
}

\author{
BUILDING A PUBLIC SERVICE MODEL IN VILLAGE: \\ BRINGING THE PUBLIC SERVICE AT THE LOCAL LEVEL
}

\author{
Marsono \\ Pusat Inovasi Pelayanan Publik, Lembaga Administrasi Negara \\ Jl. Veteran No. 10 Jakarta 10110 \\ Email:marsonoahmad@yahoo.co.id, marsono@lan.go.id,
}

Naskah diterima: 21 November 2016, revisi pertama: 7 Maret 2017, revisi kedua: 14 Maret 2017, disetujui 17 April 2017.

\begin{abstract}
Construction of village's public service model is imperative since village has more authorities as has been mandated by Law Number 6 of 2014 concerning the village. The authorities allow village government to prepare RPJMDes, APBDes, and village planning independently. Therefore, village has wider opportunities to improve its services in accordance with its nature and characteristics. In rural public service perspective, it is necessary to develop a public service model. This study concludes several things: (1) Classification, types and numbers of village services are different; (2) The village's services are mostly in the form of recommendations at first level which then should be completed at higher levels at sub district and disctrict agencies; (3) To improve the quality of village's services, they are classified into three groups, namely: (a) recommendation letter; (b) citizenship services; and (c) rural community empowerment. Furthermore, the recommended model is a dispersed model because village service is a part of public service system at sub district and disctrict levels. However, only a small part of the public services are fully completed at village government, such as administrative service.
\end{abstract}

Keywords: Capacity building, public services, the village government

\begin{abstract}
Abstrak
Pembangunan model pelayanan publik desa mendesak sejalan dengan meningkatnya kewenangan Pemerintahan Desa sebagaimana diamanatkan Undang-Undang Nomor 6 Tahun 2014 tentang Desa. Pemerintahan desa berwenang menyusun RPJMDes, APBDes, serta menyusun rencana pembangunan tahunan secara mandiri. Dengan demikian, terbuka peluang untuk memperbaiki pelayanan publik sesuai dengan sifat dan karakteristik desa. Oleh karena itu, dalam perspektif pelayanan publik desa, perlu disusun model pelayanan
\end{abstract}


publik desa sesuai dengan kewenangannya. Studi tentang pengembangan model pelayanan publik desa ini telah menghasilkan kesimpulan : (1) Klasifikasi, jenis dan jumlahnya masih berbeda-beda; (2) Secara umum pelayanan publik desa masih berupa pengantar atau rekomendasi dan penyelesaian pelayanannya berada di Kantor Kecamatan atau bahkan di Dinas Teknis Pemerintah Kabupaten/Kota; (3) Untuk meningkatkan kualitas pelayanan publik desa, maka perlu dikelompokkan menjadi tiga, yaitu: (a) surat pengantar; (b) layanan kependudukan; dan (c) pemberdayaan masyarakat. Adapun model pelayanan publik desa yang direkomendasikan adalah model terpencar, mengingat pelayanan publik desa merupakan bagian yang tak terpisahkan dari sistem pelayanan publik Kecamatan dan Pemerintah Kabupaten/Kota. Hanya sebagian kecil saja pelayanan publik desa yang betul-betul dapat diselesaikan di desa, yaitu surat pengantar.

Kata Kunci: Penguatan kapasitas, pelayanan publik, pemerintahan desa

\section{A. PENDAHULUAN}

\section{Latar Belakang}

Pelaksanaan otonomi dan demokrasi Desa yang dibingkai dengan Undang-Undang Nomor 6 Tahun 2014 tentang Desa, bukan sekadar perkara kelembagaan semata, melainkan mempunyai dasar filosofis yang dalam. Kedepan dibutuhkan bangsa yang mandiri, bermartabat, pemerintah yang kuat (berkapasitas dan bertenaga) dan demokratis. Upaya penguatan otonomi daerah dan “otonomi Desa” menjadi bagian dari cita-cita itu, sekaligus hendak membangun imajinasi Indonesia yang kuat dan sempurna, yang melampui (beyond) sentralisme dan lokalisme. NKRI akan menjadi lebih kuat bila ditopang oleh kedaulatan rakyat serta kemandirian lokal (daerah dan Desa), yakni pusat yang “menghargai” lokal dan lokal yang "menghormati” pusat. Kemandirian Desa akan menjadi fondasi dan kekuatan NKRI, oleh karenanya jika Desa selamanya marginal dan tergantung, maka justru akan menjadi beban berat pemerintah dan melumpuhkan fondasi NKRI tersebut.

Jika menilik amanat Undang-Undang 6 Tahun 2014, disebutkan bahwa pada dasarnya otonomi Desa memiliki tujuan sebagai berikut: (1) memperkuat kemandirian Desa sebagai basis kemandirian NKRI; (2) memperkuat posisi Desa sebagai subyek pembangunan; (3) mendekatkan perencanaan pembangunan ke masyarakat; (4) memperbaiki pelayanan publik dan pemerataan pembangunan; (5) menciptakan efisiensi pembiayaan pembangunan yang sesuai dengan kebutuhan lokal; (6) menggairahkan ekonomi lokal dan penghidupan masyarakat Desa; (7) memberikan kepercayaan, tanggungjawab dan tantangan bagi Desa untukmembangkitkan prakarsa dan potensi Desa; (8) menempa kapasitas Desa dalam mengelola pemerintahan dan pembangunan; (9) membuka arena pembelajaran yang sangat berharga bagi pemerintah Desa, lembaga-lembaga Desa dan masyarakat; dan (10) merangsang tumbuhnya partisipasi masyarakat lokal.

Untuk mewujudkan kondisi Desa sebagaimana tersebut di atas, tentu banyak sekali hal yang harus dilakukan oleh pemerintah, baik pusat, provinsi, Kabupaten, dan Kecamatan serta seluruh stakeholders terkait. Salah satu hal yang sangat krusial adalah terkait dengan penguatan kapasitas pelayanan publik Pemerintahan Desa. Dimana esensi desentralisasi dan otonomi daerah salah satunya adalah mendekatkan pelayanan publik kepada masyarakat. Oleh karena itu, membangun model pelayanan publik dalam Pemerintahan Desa menjadi sebuah keniscayaan dalam mendorong desentralisasi dan otonomi desa sebagai strategi dalam memperkuat NKRI kedepan.

Membangun konstruksi model pelayanan publik Desa paling tidak harus dimulai dari mengidentifikasi aspek-aspek yang berkaitan dengan manajemen pelayanan publik Desa secara 
menyeluruh. Beberapa aspek yang berpengaruh terhadap totalitas dalam pemberian pelayanan publik Desa yang berkualitas, antara lain terkait dengan: (1) pengorganisasiannya; (2) bisnis proses; (3) SDM; (4) Standar-standar; (5) IT dan sarana pendukung lainnya.

Oleh karena itu, penguatan kapasitas pelayanan publik Desa pada dasarnya adalah upayaupaya untuk mengidentifikasi, membangun, menerapkan dan mengevaluasi secara baik dan konsisten seluruh aspek-aspek pelayanan publik Desa sebagaimana tersebut di atas. Dengan demikian, akan dapat dikembangkan konstruksi model pelayanan publik Desa baik menyangkut jenis dan jumlahnya, pengorganisasiannya, ruang lingkupnya, kompetensi SDM pelayanan Desa, standar-standar pelayanannya serta penggunaan IT untuk mendukung kelancaran dan kualitas pelayanan publik Desa.

\section{Tujuan dan Manfaat}

Melalui pembahasan mengenai pengembangan konstruksi model pelayanan publik Desa dalam rangka mendekatkan pelayanan masyarakat di tingkat lokal, maka tujuan yang akan disasar adalah:

a. Melihat potret kapasitas desa dalam memberikan pelayanan publik kepada masyarakat di lingkungan pemerintahan desa;

b. Melihat gambaran model-model pelayanan publik desa sesuai dengan kewenangan, fungsi dan karakteristik yang dimiliki;

c. Menyusun konstruksi model pelayanan publik desa dalam rangka mendekatkan pelayanan kepada masyarakat desa.

Berdasarkan tujuan tersbut, maka manfaat yang akan diperoleh sebagai berikut:

a. Memperoleh berbagai informasi terkait dengan kapasitas desa dalam memberikan pelayanan publik di lingkungan pemerintahan desa;

b. Mendapat gambaran model-model pelayanan publik desa sesuai dengan kewenangan, fungsi dan karakteristik yang dimiliki;

c. Tersusunnya rekomendasi model pelayanan publik desa yang dapat dikembangkan dan direplikasi secara masif oleh pemerintahan desa.

\section{Perumusan Masalah}

Membangun konstruksi model pelayanan publik desa dalam mendekatkan pelayanan kepada masyarakat desa, tentu berangkat dari permasalahan yang dihadapi oleh pemerintah desa sampai pada pemecahan permasalahannya, oleh karena itu diperlukan perumusan masalah sebagai berikut:

a. Memahami kembali konsep pelayanan publik sesuai dengan Undang-undang Nomor 25 Tahun 2009 tentang Pelayanan Publik;

b. Menyajikan permasalahan yang dihadapi oleh desa dalam memberikan pelayanan publik kepada masyarakat;

c. Bagaimana rekomendasi model pelayanan publik desa sesuai dengan kewenangan, fungsi dan karakteristik masing-masing desa.

\section{B. METODE PENULISAN}

Metode penulisan yang digunakan dalam makalah ini adalah menggunakan pendekatan metode deskriptif analitis, dimana menjelaskan permasalahan pelayanan publik desa melalui analisa berdasarkan data-data yang ada. Berbagai data diperoleh berdasarkan permasalahan pelayanan publik yang dihadapi desa terkait dengan kapasitas yang dimiliki kewenangan, fungsi dan karakteristik 
desa sesuai dengan amanat undang-undang yang mengatur tentang pemerintahan desa. Data sekunder didapat melalui hasil penelitian yang telah dilakukan sebelumnya serta berbagai data empiris terkait dengan permasalahan yang dihadapi desa dalam memberikan pelayanan publik kepada warga masyarakatnya. Selanjutnya permasalahan tersebut perlu diselesaikan melalui penyusunan model-model pelayanan publik desa sesuai dengan kewenangan, fungsi dan karakteristik masingmasing desa, sehingga tujuan utama pembentukan desa yang telah diamanatkan peraturan perundangudangan benar-benar dapat terwujud, khususnya terkait dengan upaya mendekatkan pelayanan publik langsung ke masyarakat terbawah serta tercapainya kesejahteraan masyarakat desa.

\section{KERANGKA KONSEP}

\section{Konstruksi Pelayanan Publik Dalam Undang-Undang Desa}

Undang-Undang Nomor 6 Tahun 2014 tentang Desa merupakan instrumen untuk membangun visi menuju kehidupan Desa yang mandiri, demokratis dan sejahtera. Kemandirian Desa bukanlah kesendirian Desa dalam menghidupi dirinya sendiri serta tidak berada di ruang yang hampa politik, tetapi juga terkait dengan dimensi keadilan yang berada dalam konteks relasi antara Desa (sebagai entitas lokal) dengan kekuatan supraDesa (pusat dan daerah) yang lebih besar. Secara lokal-internal, kemandirian Desa berarti kapasitas dan inisiatif lokal yang kuat. Inisiatif lokal adalah gagasan, kehendak dan kemauan entitas Desa yang berbasis pada kearifan lokal, komunalisme dan modal sosial (kepemimpinan, jaringan dan solidaritas sosial). Dengan demikian, inisiatif lokal yang kuat merupakan fondasi lokal bagi kemandirian Desa.

Perspektif pelayanan publik Desa, berdasarkan amanat Undang-undang Republik Indonesia Nomor 6 Tahun 2014 Pasal 4 butir f, dinyatakan bahwa pengaturan desa bertujuan meningkatkan pelayanan publik bagi warga masyarakat desa guna mempercepat perwujudan kesejahteraan umum. Sedangkan dalam Pasal 7 ayat (3) butir c, disebutkan bahwa penataan Desa dimaksudkan untuk mempercepat proses pelayanan publik. Selanjutnya Pasal 67 ayat (2) butir e, menyatakan bahwa Desa berkewajiban memberikan dan meningkatkan pelayanan kepada masyarakat desa. Lebih lanjut, dalam Pasal 68 ayat (1) butir b disebutkan bahwa masyarakat desa berhak memperoleh pelayanan yang sama dan adil.

Isu kesejahteraan mencakup dua komponen besar, yakni penyediaan layanan dasar (pangan, papan, pendidikan dan kesehatan) dan pengembangan ekonomi Desa yang berbasis pada potensi lokal. Kemandirian dan demokrasi Desa merupakan alat dan peta jalan untuk mencapai kesejahteraan rakyat Desa. Desentralisasi memungkinkan alokasi sumberdaya kepada Desa, dan demokrasi memungkinkan pengelolaan sumber daya Desa berpihak pada rakyat Desa. Hak Desa untuk mengelola sumberdaya alam, misalnya, merupakan modal yang sangat berharga bagi ekonomi rakyat Desa. Demikian juga dengan alokasi dana Desa yang lebih besar akan sangat bermanfaat untuk menopang fungsi Desa dalam penyediaan layanan dasar warga Desa. Namun, kesejahteraan rakyat Desa yang lebih optimal tentu tidak mungkin mampu dicakup oleh pemerintah Desa semata, karena itu dibutuhkan juga kebijakan pemerintah yang responsif dan partisipatif, yang berorientasi pada perbaikan pelayanan dasar dan pengembangan ekonomi lokal.

Secara garis besar konstruksi penataan Pemerintahan Desa yang tertuang dalam UndangUndang Nomor 6 Tahun 2014 tentang Desa dan PP pelaksanaannya dapat dilihat gambar 1 sebagai berikut: 


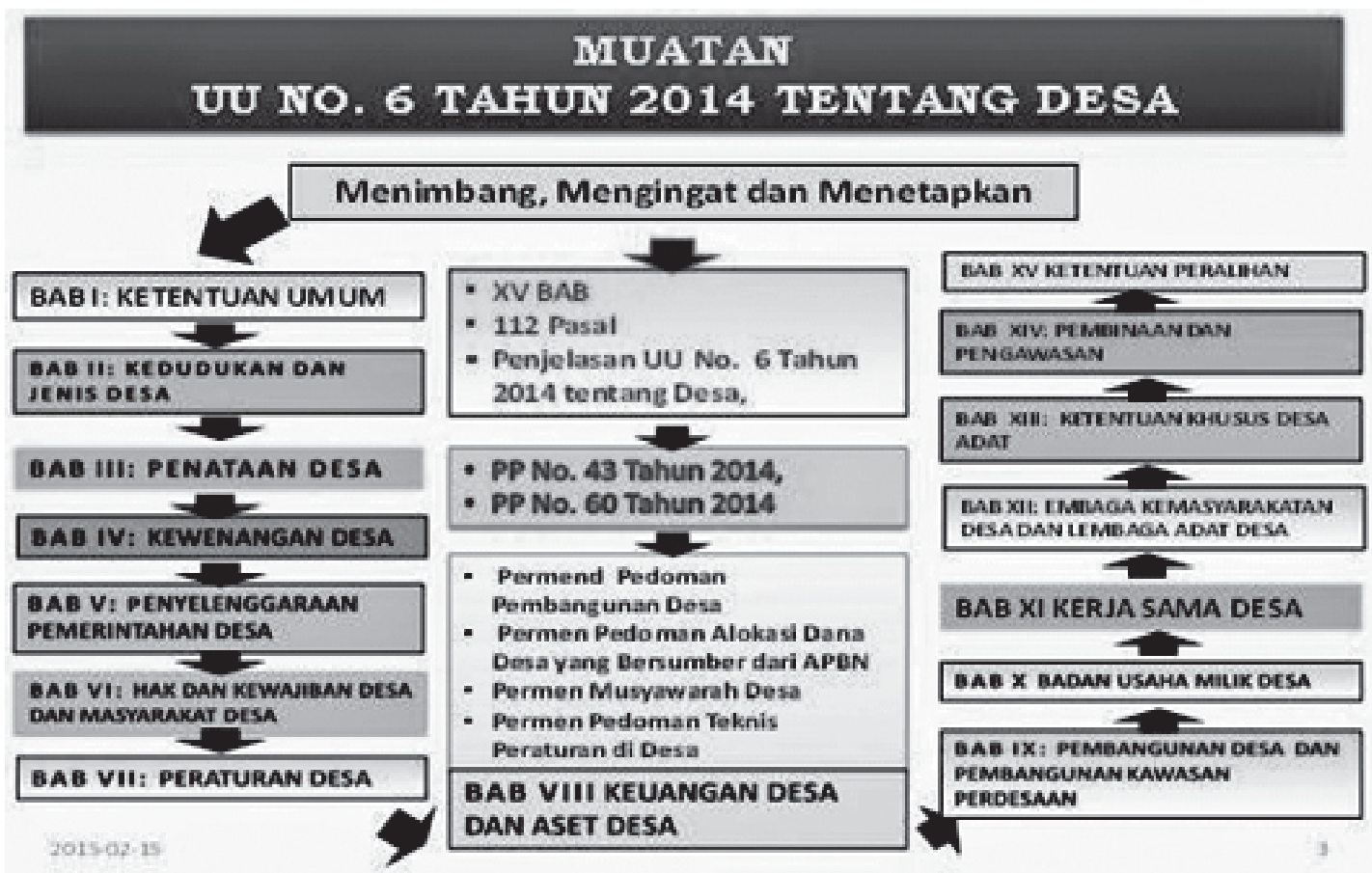

Gambar 1.

Konstruksi Peraturan Perundangan tentang Desa

\section{Metode Pemodelan Pelayanan Publik Desa}

Dalam studi pengembangan model pelayanan publik desa ini, pendekatan yang digunakan adalah diskriptif eksploratif. Dimana pada tahap awal dilakukan pendiskripsian terhadap data empiris berupa pola atau model pelayanan publik desa yang selama ini dilakukan. Disamping itu, pemanfaatan data empiris pelayanan publik desa juga akan dipergunakan dalam menentukan gap antara model pelayanan publik desa exsisting dengan model pelayanan publik desa kedepan sesuai dengan kewenangan yang dimiliki berdasarkan Undang-Undang Desa.

Sedangkan terkait dengan pendekatan eksploratif, pada prinsipnya bahwa kewenangan desa yang telah diamanatkan Undang-Undang Desa tersebut harus diidentifikasi, ditelaah, diekplorasi sehingga kewenangan-kewenangan tersebut dapat diwujudkan kedalam tindakan-tindakan nyata berupa kegiatan-kegiatan pelayanan publik kepada masyarakat desa. Dengan demikian, maka pembangunan model pelayanan publik desa pada dasarnya adalah mengisi gap antara pelayanan publik desa existing dan jenis, jumlah serta lingkup pelayanan publik desa berdasarkan kewenangan yang dimiliki berdasarkan Undang-undang Desa.

Selanjutnya bagaimana perspektif model pelayanan publik desa kedepan, yang memiliki berbagai karakteristik yang berbeda-beda. Dari aspek tipologi ada desa adat, yang juga memilki berbagai bentuk yang juga berbeda-beda. Sedangkan dari aspek geografis, karakteristik desa dapat dibedakan menjadi desa industri, desa maritim, desa pertanian dan desa wisata. Berbagai karakteristik desa tersebut akan sangat berpengaruh terhadap pola/model pelayanan publik desa masing-masing. Contoh untuk desa pertanian, kebutuhan pelayanan publik diluar kebutuhan dasar dan administratif, tentu akan lebih diutamakan pada pelayanan penyuluhan, pengadaan bibit, pengadaan pupuk, pengolahan hasil panen serta pemasaran hasil panen. Begitupun juga akan berlaku untuk desa-desa dengan karakteristik yang berbeda, baik berdasarkan tipologi maupun karakteristik berdasarkan geografis. 
Berikut ini adalah kerangka pemodelan dalam membangun model pelayanan publik pemerintah desa pasca Undang-Undang Nomor 6 Tahun 2014.

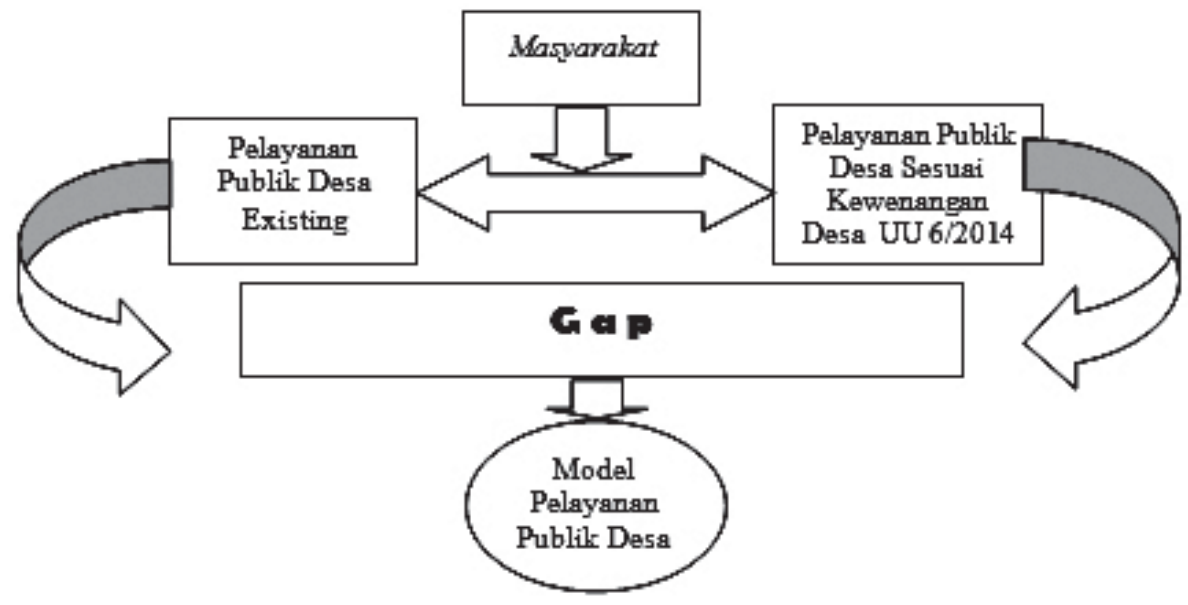

Gambar 2.

Kerangka Pemodelan Pelayanan Publik Desa

\section{Kebijakan dan Konsepsi Pelayanan Publik}

Pelayanan publik dapat diartikan sebagai pemberian layanan (melayani) keperluan orang atau masyarakat yang mempunyai kepentingan pada organisasi itu sesuai dengan aturan pokok dan tata cara yang telah ditetapkan. Sebagaimana telah dikemukakan terdahulu bahwa pemerintahan pada hakekatnya adalah pelayanan kepada masyarakat. Ia tidaklah diadakan untuk melayani dirinya sendiri, tetapi untuk melayani masyarakat serta menciptakan kondisi yang memungkinkan setiap anggota masyaraakat mengembangkan kemampuan dan kreativitasnya demi mencapai tujuan bersama (Rasyid, 1998). Karenanya birokrasi publik berkewajiban dan bertanggung jawab untuk memberikan layanan baik dan profesional. Pelayanan publik (public services) oleh birokrasi publik tadi adalah merupakan salah satu perwujudan dari fungsi aparatur negara sebagai abdi masyarakat di samping sebagai abdi negara. Pelayanan publik (public services) oleh birokrasi publik dimaksudkan untuk mensejahterakan masyarakat (warga negara) dari suatu negara kesejahteraan (welfare state).

Pemberian pelayanan publik yang berkualitas pada hakekatnya adalah pemenuhan pelayanan kepada masyarakat yang merupakan perwujudan kewajiban pemerintah sebagai agent dan masyarakat sebagai principal (pemegang kedaulatan). Kewajiban pemberian pelayanan tersebut mencakup pelayanan yang bersifat welfare (kesejahteraan) seperti kesehatan, pendidikan, sandang dan pangan, maupun pelayanan terkait dengan barang publik, jasa publik, pelayanan administratif serta berbagai jenis pelayanan perizinan dan non perizinan. Oleh karena itu, peran dan tanggung jawab pemerintah sebagai regulator, fasilitator dan katalisator menjadi sangat penting dalam mendorong dan mewujudkan pelayanan publik yang inovatif, kontekstual dan partisipatoris (LAN, 2013).

Sejalan dengan hal tersebut di atas, beberapa agenda prioritas Rencana Pembangunan Jangka Menengah Nasional (RPJMN) 2015-2019 bidang pelayanan publik yang harus dicapai oleh Kementerian/Lembaga dan Pemerintah Daerah antara lain mencakup: (a) peningkatan kualitas implementasi Undang-Undang Nomor 25 Tahun 2009 tentang Pelayanan Publik; (b) modernisasi sistem dan manajemen pelayanan publik (SDM, ICT, Standar Pelayanan); (c) monitoring dan supervisi kinerja pelayanan publik; (d) membuka ruang partisipasi publik melalui Citizen Charter; dan (e) penguatan integritas dalam pelayanan publik. 
Pengertian pelayanan publik berdasarkan Pasal 1 Ayat (1) UU Nomor 25 Tahun 2009 tentang Pelayanan Publik, disebutkan bahwa "pelayanan publik adalah kegiatan atau rangkaian kegiatan dalam rangka pemenuhan kebutuhan pelayanan sesuai dengan peraturan perundangundangan bagi setiap warga negara dan penduduk atas barang, jasa, dan / atau pelayanan administratifyang disediakan oleh penyelenggara pelayanan publik". Selanjutnya berdasarkan Pasal 1 butir 1 Peraturan Pemerintah Nomor 96 Tahun 2012 tentang Pelaksanaan UU Nomor 25 Tahun 2009 tentang Pelayanan Publik, disebutkan bahwa pengertian pelayanan publik adalah kegiatan atau rangkaian kegiatan dalam rangka pemenuhan kebutuhan pelayanan sesuai dengan peraturan perundang-undangan bagi setiap warga negara dan penduduk atas barang, jasa, dan/atau pelayanan administratif yang disediakan oleh penyelenggara pelayanan publik.

Secara konseptual pelayanan publik secara umum dibagi kedalam tiga kelompok jenis pelayanan, yaitu : Pertama, Kelompok Pelayanan Administratif, yaitu pelayanan yang menghasilkan berbagai bentuk dokumen resmi yang dibutuhkan oleh publik, misalnya status kewarganegaraan, sertifikat kompetensi, kepemilikan atau penguasaan terhadap suatu barang dan sebagainya. Contoh : KTP, Akta Kelahiran, Akta Kematian, SIM, STNK, BPKB, IMB, Paspor dan sebagainya. Kedua, Kelompok Pelayanan Barang yaitu pelayanan yang menghasilkan berbagai bentuk/jenis barang yang digunakan oleh publik, misalnya jaringan telepon, tenaga listrik, air bersih dan sebagainya. Ketiga, Kelompok Pelayanan Jasa, yaitu pelayanan yang menghasilkan berbagai jasa yang dibutuhkan oleh publik, misalnya pendidikan, pemeliharaan kesehatan, penyelenggaraan jasa transportasi, pos dan sebagainya.

Adapun ruang lingkup pelayanan publik berdasarkan Pasal Pasal 5 Ayat (1) disebutkan bahwa ruang lingkup pelayanan publik meliputi pelayanan barang publik dan jasa publik serta pelayanan administratif yang diatur dalam peraturan perundang-undangan. Secara lebih jelas terkait dengan ruang lingkup pelayanan publik dapat dilihat pada Tabel 1 sebagai berikut.

Tabel 1.

Ruang Lingkup Pelayanan Publik

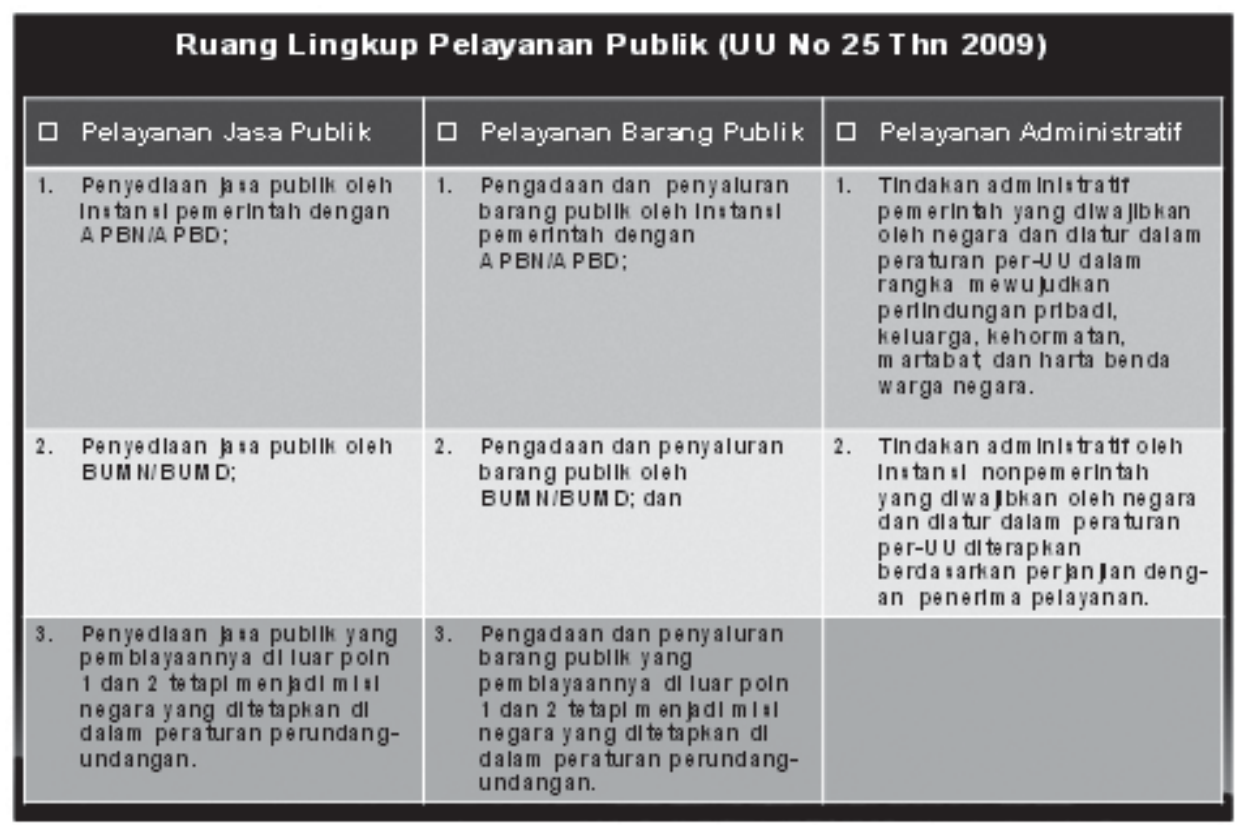

Sumber : UU Nomor 25 Tahun 2009. 
Merujuk pada Undang-undang Pelayanan Publik tersebut, setidaknya ada empat hal yang harus dilakukan oleh pemerintah desa, meliputi: 1) Menyusun dan menetapkan standar pelayanan; 2) Menyusun, menetapkan, dan mempublikasikan maklumat pelayanan; 3) Menempatkan pelaksana yang kompeten; dan 4) Menyediakan sarana, prasarana, dan/atau fasilitas pelayanan publik yang mendukung terciptanya iklim pelayanan yang memadai.

Pada dasarnya karakteristik pelayanan publik yang diselenggarakan oleh pemerintah adalah: (1) memiliki dasar hukum yang jelas dalam penyelenggaraannya,(2) memiliki kelompok kepentingan yang luas termasuk kelompok sasaran yang ingin dilayani (wide stakeholders), (3) memiliki tujuan sosial, (4) dituntut untuk akuntabel kepada publik, (5) memiliki konfigurasi indikator kinerja yang perlu kelugasan (complex and debated performance indicators), serta (6) seringkali menjadi sasaran isu politik (LAN, 2006).

Berbeda dengan pelayanan yang diberikan oleh pemerintah, penyediaan pelayanan oleh sektor swasta memiliki karakteristik: (1) didasarkan kepada kebijakan Dewan Direksi (board of directors), (2) terfokus pada pemegang saham (shareholders) dan manajemen, (3) memiliki tujuan mencari keuntungan, (4) harus akuntabel pada kalangan terbatas (limited shareholders), (5) kinerjanya ditentukan atas dasar kinerja manajemen, termasuk didalamnya kinerja finansial, serta (6) tidak terlalu terkait dengan isu politik.

Terkait dengan pengertian dan konsepsi pelayanan publik, Pamudji (1994) mengemukakan "pelayanan publik adalah berbagai kegiatan yang bertujuan memenuhi kebutuhan masyarakat akan barang-barang dan jasa-jasa”. Hal yang sama dikemukakan Widodo (2001 : 269) bahwa :"Pelayanan publik sebagai pemberian layanan (melayani) keperluan orang atau masyarakat yang mempunyai kepentingan pada organisasi itu sesuai dengan aturan pokok dan tata cara yang ditetapkan”.

Selanjutnya Boediono (2003) menyatakan bahwa : "pelayanan pelanggan adalah upaya atau proses yang secara sadar dan terencana dilakukan organisasi atau badan usaha agar produk/jasanya menang dalam persaingan melalui pemberian/penyajian pelayanan kepada pelanggan sehingga tercapai kepuasaan optimal bagi pelanggan”. Sedangkan Djaenuri (1999 : 15) mendefinisikan tentang pelayanan masyarakat adalah " Suatu kegiatan yang merupakan perwujudan dari tugas umum pemerintahan mengenai bidang tugas pokok suatu instansi untuk dapat melayani kebutuhan masyarakat secara maksimal”.

Sedangkan Ndraha (1996) mengemukakan bahwa : "Pelayanan pemerintah kepada masyarakat adalah terkait dengan suatu hak dan lepas dari persoalan apakah pemegang hak itu dibebani suatu kewajiban atau tidak. Dalam hal ini dikenal adalah hak bawaan (sebagai manusia) dan hak berian. Hak bawaan itu selalu bersifat individual dan pribadi, sedangkan hak berian meliputi hak sosial politik dan hak individual. Lembaga yang berkewajiban memenuhi hak tersebut adalah pemerintah. Kegiatan pemerintah untuk memenuhi hak bawaan dan hak berian itulah yang disebut pelayanan pemerintah kepada masyarakat termasuk pribadi-pribadi pemilik hak bawaan”.

Selanjutnya dalam perkembangan konsep pelayanan publik, seiring dengan reformasi di sektor publik/pemerintahan yang mulai mengadopsi pendekatan-pendekatan pelayanan yang dilakukan di sektor privat/bisnis dalam rangka kompetisi untuk memberikan yang terbaik kepada masyarakat. Dalam konteks ini masyarakat mulai ditempatkan bukan hanya sebagai penerima pelayanan dan harus mengikuti kemauan yang memberi pelayanan, akan tetapi masyarakat juga ditempatkan sebagai pelanggan atau konsumer, yang menjadi penentu kualitas pelayanan yang diberikan.

Adapun terkait dengan penguatan pentingnya peningkatan kualitas pelayanan publik di daerah, juga telah diamanatkan Undang-Undang Nomor 23 Tahun 2014 tentang Pemerintahan Daerah, dimana disebutkan bahwa Penyelenggaraan Pemerintahan Daerah diarahkan untuk mempercepat 
terwujudnya kesejahteraan masyarakat melalui peningkatan pelayanan, pemberdayaan, dan peran serta masyarakat, serta peningkatan daya saing daerah. Upaya penyediaan pelayanan yang berkualitas antara lain dapat dilakukan dengan memperhatikan ukuran-ukuran apa saja yang menjadi kriteria kinerja pelayanan.

Berdasarkan Kep MenPAN No 63 Tahun 2003 kriteria-kriteria pelayanan tersebut adalah : (1) Kesederhanaan, yaitu bahwa tata cara pelayanan dapat diselenggarakan secara mudah, lancar, cepat, tidak berbelit-belit, mudah dipahami dan dilaksanakan oleh pelanggan; (2) Reliabilitas, meliputi konsistensi dari kinerja yang tetap dipertahankan dan menjaga saling ketergantungan antara pelanggan dengan pihak penyedia pelayanan , seperti menjaga keakuratan perhitungan keuangan, teliti dalam pencatatan data dan tepat waktu; (3) Tanggung jawab dari para petugas pelayanan yang meliputi pelayanan sesuai dengan urutan waktunya, menghubungi pelanggan secepatnya apabila terjadi sesuatu yang perlu segera diberitahukan; (4) Kecakapan para petugas pelayanan, yaitu bahwa para petugas pelayanan menguasai keterampilan dan pengetahuan yang dibutuhkan; (5) Pendekatan kepada pelanggan dan kemudahan kontak pelanggan dengan petugas. Petugas pelayanan harus mudah dihubungi oleh pelanggan, tidak hanya dengan pertemuan secara langsung, tetapi juga melalui telepon atau internet. Oleh karena itu, lokasi dari fasilitas dan operasi pelayanan juga harus diperhatikan; (6) Keramahan, meliputi kesabaran, perhatian dan persahabatan dalam kontak antara petugas pelayanan dan pelanggan. Keramahan hanya diperlukan jika pelanggan termasuk dalam konsumen konkret. Sebaliknya, pihak penyedia layanan tidak perlu menerapkan keramahan yang berlebihan jika layanan yang diberikan tidak dikonsumsi para pelanggan melalui kontak langsung; (7) Keterbukaan, yaitu bahwa pelanggan bisa mengetahui seluruh informasi yang mereka butuhkan secara mudah dan gamblang, meliputi informasi mengenai tata cara, persyaratan, waktu penyelesaian, biaya dan lain-lain; (8) Komunikasi antara petugas dan pelanggan. Komunikasi yang baik dengan pelanggan adalah bahwa pelanggan tetap memperoleh informasi yang berhak diperolehnya dari penyedia pelayanan dalam bahasa yang mereka mengerti; (9) Kredibilitas, meliputi adanya saling percaya antara pelanggan dan penyedia pelayanan, adanya usaha yang membuat penyedia pelayanan tetap layak dipercayai, adanya kejujuran kepada pelanggan dan kemampuan penyedia pelayanan untuk menjaga pelanggan tetap setia; (10) Kejelasan dan kepastian, yaitu mengenai tata cara, rincian biaya layanan dan tata cara pembayarannya, jadwal waktu penyelesaian layanan tersebut. Hal ini sangat penting karena pelanggan tidak boleh ragu-ragu terhadap pelayanan yang diberikan; (11) Keamanan, yaitu usaha untuk memberikan rasa aman dan bebas pada pelanggan dari adanya bahaya, resiko dan keragu-raguan. Jaminan keamanan yang perlu kita berikan berupa keamanan fisik, finansial dan kepercayaan pada diri sendiri; (12) Mengerti apa yang diharapkan pelanggan. Hal ini dapat dilakukan dengan berusaha mengerti apa saja yang dibutuhkan pelanggan. Mengerti apa yang diinginkan pelanggan sebenarnya tidaklah sukar. Dapat dimulai dengan mempelajari kebutuhan-kebutuhan khusus yang diinginkan pelanggan dan memberikan perhatian secara personal; (13) Kenyataan, meliputi bukti-bukti atau wujud nyata dari pelayanan, berupa fasilitas fisik, adanya petugas yang melayani pelanggan, peralatan yang digunakan dalam memberikan pelayanan, kartu pengenal dan fasilitas penunjang lainnya; (14)Efisien, yaitu bahwa persyaratan pelayanan hanya dibatasi pada hal-hal yang berkaitan langsung dengan pencapaian sasaran pelayanan dengan tetap memperhatikan keterpaduan antara persyaratan dengan produk pelayanan; dan (15) Ekonomis, yaitu agar pengenaan biaya pelayanan harus ditetapkan secara wajar dengan memperhatikan nilai barang/jasa dan kemampuan pelanggan untuk membayar.

Mengenai kualitas pelayanan publik, Goetsch dan Davis (2002) mendefinisikan kualitas pelayanan sebagai suatu kondisi dinamis yang berhubungan dengan produk, jasa, manusia, proses dan lingkungan yang memenuhi atau melebihi harapan. Kualitas pelayanan juga diartikan sebagai 
sesuatu yang berhubungan dengan terpenuhinya harapan/ kebutuhan pelanggan, di mana pelayanan dikatakan berkualitas apabila dapat menyediakan produk dan jasa (pelayanan) sesuai dengan kebutuhan dan harapan pelanggan.

Senada dengan pendapat di atas, Evans dan Lindsay (1997) berpendapat bahwa kualitas pelayanan dapat dilihat dari berbagai sudut. Jika dilihat dari sudut pandang konsumen, maka kualitas pelayanan selalu dihubungkan dengan sesuatu yang baik/prima (excellent). Jika kualitas pelayanan dipandang dari sudut "product based", maka kualitas pelayanan dapat didefinisikan sebagi suatu fungsi yang spesifik, dengan variabel pengukuran yang berbeda-beda dalam memberikan penilaian kualitas sesuai dengan karakteristik produk yang bersangkutan. Kualitas pelayanan jika dilihat dari sudut "user based", maka kualitas pelayanan adalah sesuatu yang diinginkan oleh pelanggan atau tingkat kesesuaian dengan keinginan pelanggan. Sedangkan, jika dilihat dari “value based”, maka kualitas pelayanan merupakan keterkaitan antara kegunaan atau kepuasan dengan harga.

Berdasarkan konsepsi kualitas pelayanan publik tersebut di atas, dapat disimpulkan bahwa pelayanan publik desa yang berkualitas, hanya akan diwujudkan apabila dalam pemerintahan desa terdapat sistem pelayanan yang mengutamakan kepentingan warga masyarakat desa sebagai pengguna jasa pelayanan dan perangkat desa memiliki kepedualian terhadap kebutuhan dan kepentingan warga masyarakat desa.

\section{HASIL DAN PEMBAHASAN}

\section{Pelayanan Publik Desa: Current Conditions}

Studi tentang pelayanan publik desa telah dilakukan Joni Suwarno (2012) yang telah dipublikasikan dalam Jurnal Ilmu Politik dan Pemerintahan Lokal, Volume I Edisi 2, Juli-Desember 2012. Adapun judul penelitiannya adalah: "Kualitas Pelayanan Pemerintahan Desa (Studi Pelayanan KTP dan KK di Desa Teluk Kepayang Kecamatan Kusan Hulu Kabupaten Tanah Bumbu)”.

Hasil studi tersebut menunjukkan bahwa bentuk pelayanan yang diberikan oleh Desa Teluk Kepayang dalam hal administrasi kependudukan adalah berupa rekomendasi dari desa untuk dapat diteruskan ke Dinas Kependudukan dan Catatan Sipil (Disdukcapil) melalui Kantor Kecamatan Kusan Hulu. Namun pelayanan yang tidak resmi lainnya adalah adanya masyarakat yang meminta pengurusan sampai selesai atas KTP dan KK yang berimplikasi kepada biaya tambahan seperti biaya transportasi serta biaya tak terduga lainnya.

Kualitas pelayanan publik yang diberikan oleh Pemerintah Desa Teluk Kepayang Kecamatan Kusan Hulu Kabupaten Tanah Bumbu khususnya dalam pemberian dokumen surat pengantar pembuatan atau pencetakan Kartu Tanda Penduduk (KTP) dan Kartu Keluarga (KK) masih belum maksimal dalam hal ketepatan waktu, prosedur pembiayaan dan tingkat kesalahan pencetakan dokumen. Dengan demikian artinya bahwa kualitas pelayanan publik di kantor desa Teluk Kepayang masih belum begitu memuaskan.

Selanjutnya dapat disimpulkan bahwa secara umum, pelayanan yang diberikan Pemerintahan Desa Teluk Kepayang kurang memadai. Seperti jumlah petugas yang memberikan pelayanan saat ini hanya terdiri dari tujuh orang yang terdiri dari Kepala Desa, Sekretaris Desa, Kaur Pemerintahan, Bendahara Desa, Kaur Pembangunan, Kaur Umum dan Tata Usaha. Ditinjau dari segi peralatan dan fasilitas pada kantor Pemerintahan Teluk Kepayang terlihat bahwa ketersediaan peralatan sangat tidak memadai, dimana fasilitas penunjang kerja yang tersedia hanya terdiri dari 2 mesin ketik. Jadi pegawai dalam memberikan pelayanan masih menggunakan mesin ketik manual.

Sejalan dengan kondisi di atas, Yeni Agustina juga telah menyampaikan hasil studinya dalam eJurnal Administrasi Negara, Fisip UNMUL, Volme 3 Nomor 4 Tahun 2015. Terkait dengan pelayanan 
publik desa yang menyatakan bahwa terdapat kendala internal dan eksternal dalam pelaksanaan pelayanan publik di Kantor Desa Sukoulyo Kecamatan Long Iram Kabupaten Kutai Barat. Kendala internal terkait dengan rendahnya tingkat pendidikan kepala desa/aparat yang sebagian besar hanya lulusan Sekolah Dasar (SD). Sedangkan kendala eksternal terkait dengan rendahnya partisipasi masyarakat dalam setiap program dan kebijakan yang dihasilkan kepala desa.

Masih terkait dengan kondisi pelayanan publik desa, hasil studi Clement Belly Heden Higau terhadap Pelaksanaan Administrasi Pemerintahan Desa Dalam Meningkatkan Pelayanan Masyarakat Di Desa Matalibaq Kecamatan Long Hubung Kabupaten Mahakam Ulu, yang dituangkan dalam eJurnal Ilmu Pemerintahan, Fisip UNMUL, Volume 3 Nomor 3 Tahun 2015 menyatakan bahwa "kurangnya kemampuannya aparatur desa untuk memahami dan mengerti administrasi yang baik, terbatasnya sarana dan prasarana untuk menunjang kegiatan administrasi, kurang efektifnya aparat desa dalam menjalankan fungsinya sehingga kegiatan sering tertunda. Rendahnya kesedaran masyarakat terhadap pentingnya identitas diri seperti KTP, KK dan surat-surat yang berkaitan dengan kehidupan berbangsa dan bernegara', kondisi tersebut sudah barang tentu akan berpengaruh terhadap kualitas pelayanan publik desa.

Memperkuat temuan di atas, Dewi Novita Sari melakukan studi Persepsi Masyarakat Randukuning Terhadap Kinerja Aparatur Pemerintah Desa, yang dimuat dalam Jurnal Ilmiah Univ. Veteran Semarang, Volume 2 Nomor 1, November 2014, menyatakan bahwa "sebagian besar masyarakat masih belum puas dalam pelayanan publik yang dilakukan aparatur desa dikarenakan bila ada keperluan masih harus menunggu aparatur datang. Seharusnya aparatur desa bisa disiplin waktu dalam bekerja untuk melayani masyarakat.

Jenis dan bentuk pelayanan publik desa masih menunjukkan adanya perbedaan dari setiap desa, studi yang dilakukan Arizki Afrizal Ahmad tentang Kinerja Pemerintahan Desa Sebagai Penyedia Pelayanan Publik Di Desa Wringinpitu Kecamatan Mojowarno Kabupaten Jombang dalam Jurnal Pendidikan Kewarganegaraan Universitas Negeri Malang, Volume 1, No.1 Tahun 2014, menyatakan bahwa "terdapat pelayanan administrasi dan pelayanan non administrasi. pelayanan administrasi yang terdapat di Desa Wringinpitu yaitu terdapat pelayanan umum dan pelayanan penduduk. Sedangkan pelayanan non administrasi terdapat pelayanan secara fisik dan non fisik, pelayanan fisik berupa pembangunan infrastruktur desa, pelayanan non fisik berupa pelaynan dalam bentuk pelatihan dan pemberdayaan masyarakat. Jenis dan bentuk pelayanan publik yang terdapat di Desa Wringinpitu merupakan ketentuan yang dibuat sendiri dan dituangkan dalam peraturan Desa Wringinpitu, hal ini merupakan suatu kebijakan yang dilakukan demi memenuhi kepentingan masyarakat secara keseluruhan”.

Sejalan dengan kondisi di atas, Kepala Desa Sukamanah, Kecamatan Megamendung, Kabupaten Bogor, menyatakan bahwa beberapa pelayanan yang bersifat administratif memang sudah bisa diselesaikan di Desa Sukamanah, namun bentuknya masih berupa pengantar saja. Setelah itu, masyarakat datang sendiri ke dinas terkait untuk melanjutkan pengurusan pelayanannya. Lebih lanjut dikatakan bahwa ada beberapa bentuk pelayanan administratif lainnya yang disesuaikan dengan hukum adat masyarakat lokal, seperti pengurusan peralihan hak atas tanah dan bangunan, pembagian waris dan sebagainya dimana pelayanan ini dilakukan atas sepengetahuan pemerintah daerah setempat. Selain pelayanan yang bersifat administratif, Desa Sukamanah sudah memberikan pelayanan non administratif yakni berupa kegiatan pemberdayaan masyarakat desa untuk pembangunan yang dikemas dalam “Geser” (Gerakan Sebungkus Rokok untuk pembiayaan pembangunan yang tidak masuk ke dalam APBD, APBN, dan APBDes), Gerakan Membangun untuk Petani, serta untuk pendidikan berupa SMU Gratis bagi masyarakat kurang mampu. 
Data empiris lain terkait dengan pelayanan publik desa, adalah hasil visitasi Pusat Inovasi Pelayanan Publik ke beberapa desa seperti Desa Lambangsari, Kecamatan Tambun Selatan, Kabupaten Bekasi Jawa Barat, Desa Gabus, Kecamatan Ngrampal, Kabupaten Sragen Jawa Tengah serta Desa Lebo, Kecamatan Sidoarjo, Kabupaten Sidoarjo dan Desa Masangan, Kecamatan Bangil, Kabupaten Pasuruan Jawa Timur, telah menemukan kondisi bahwa pelayanan di desa hanya bersifat administratif dan masih berupa pengantar.

Selanjutnya terkait dengan pelaksanaan pelayanan publik desa saat ini, Sekretaris Camat Sidoarjo Jawa Timur (2015), menyatakan bahwa : (1) sudah ada sistem Pelayanan Kecamatan Terpadu (PATEN); (2) pelayanan tidak ada yang selesai di desa karena bersikap rekomendasi yang harus ditandatangani camat (antar provinsi), sekcam, atau kasubbid pelayanan kecamatan (dalam hitungan menit); dan (3) pelayanan publik yang selesai di tingkat kecamatan: pengantar kegiatan kades, surat keterangan waris (jika tidak untuk keperluan sertifikat ke BPN, KTP sementara (KTP kertas), IMB 200 m ke bawah, Ijin Keramaian (dengan Polsek).

Sejalan dengan penjelasan Sekretaris Camat Sidoarjo tersebut di atas, Lisbetty B. Tambunan (2015), pejabat Direktorat Jenderal Bina Pemerintahan Desa Kemendagri, menyatakan bahwa "menurut PP Nomor 43 Tahun 2014, dari 4 (empat) urusan pemerintah yang menjadi kewenangan desa, kewenangan yang paling mendasar dan dapat diselesaikan di desa hanya 2 (dua) kewenangan, yakni kewenangan berdasarkan hak asal usul dan kewenangan lokal berskala desa. Dalam ranah tersebutlah desa dapat menciptakan dan mengembangkan inovasi yang seluas-luasnya demi terselenggaranya pelayanan yang prima bagi masyarakat desa”.

Selanjutnya terkait dengan jenis dan jumlah pelayanan publik desa, beberapa contoh terkait dengan penyelenggaraan pelayanan publik di Desa Temanggung dikelompokkan menjadi dua (2), yaitu: (1) kelompok surat dan (2) kelompok PBB. Untuk kelompok surat memiliki jenis layanan sebagai berikut: (a) SKCK; (b) SKTM; (c) Nikah/Cerai; (d) Kematian; (e) Kelahiran; (f) KTP/ KK; (g) Pindah/Datang; (h) Keterangan Usaha; (i) Legalitas Usaha; (j) Legalisasi; (k) Keterangan Domisili; (l) Keterangan Waris; (m) Perizinan; (n) Sertifikat; dan (2) Kelompok PBB yaitu Mutasi PBB.

Sedangkan jenis dan jumlah pelayanan desa di Desa Ngargomulyo dikelompokkan menjadi tiga (3) kelompok, yaitu: (1) kelompok surat; (2) kelompok laporan; dan (3) kelompok pencarian data. Layanan kelompok surat meliputi: (a) Pengantar SKCK; (b)Pengantar Surat Pindah; (c) Pengantar nikah; (d) Pengentar Akta Kelahiran/Kematian; (e) Pengantar KK; (f) Pengantar KTP; (g) Pengantar SKTM; (h) Pengantar Rujukan; (i) Pengantar Pengajuan Kredit; (j) Pengantar Mutasi SPPT; (k) Pengantar Mutasi Sertifikat; (l) Pelayanan PBB; (m) Prizinan; (n) Keterangan Usaha; (o) Pengantar SIM; dan (2) Kelompok Laporan dan (3) Pencarian Data.

Berdasarkan uraian tersebut di atas, dapat diketahui bahwa pelayanan publik desa berdasarkan jenis dan jumlahnya masih berbeda-beda. Disamping itu, klasifikasinya juga masih berbeda-beda, ada yang klasifikasinya surat dengan segala jenisnya, ada juga surat pengantar dengan segala jenisnya. Berdasarkan kondisi empiris diketahui bahwa pelayanan publik desa secara umum berupa pengantar atau rekomendasi saja dan penyelesian pelayanannya berada di Kantor Kecamatan atau bahkan di Dinas Teknis Pemerintah Kabupaten. Beberapa pelayanan publik di salah satu desa di Kabupaten Bekasi antara lain meliputi: (1) Surat Pengantar Pembuatan KTP; (2) Surat Pengantar Akte Kelahiran; (3) Surat Keterangan Domisili; (4) Surat Pengantar Nikah; (5) Surat Keterangan Sudah/Belum Menikah; (6) Surat Keterangan Tidak Mampu (SKTM); (7) Surat Keterangan Pindah Penduduk; (80). Surat Pengantar IMB; (9) Surat Keterangan Duda/Janda; (10) Surat Keterangan Kematian; (11) Surat Keterangan Kelahiran; (12) Surat Pengantar Calon Tenaga Kerja; (13) Surat Keterangan Tanah; (14) Surat Pengantar Izin Keramaian; (15) Legalisir; (16) Surat Keterangan Usaha; dan 
(17) Surat Pengantar SKCK. Hal yang terpenting terkait dengan pemodelan pelayanan publik desa adalah layanan publik apa saja yang menjadi kewenangan desa dan selesai di desa. Oleh Karena itu, gambaran current condition pelayanan publik desa menjadi sangat penting dalam rangka membangun model tersebut.

\section{Membangun Model Pelayanan Publik Desa}

Dalam konteks pemerintahan desa, dengan semakin kuatnya otonomi pemerintahan desa maka otorisasi pelayanan publik pemerintahan desa harus segera diwujudkan. Lantas bagaimana mewujudkan dan melaksanakan otorisasi pelayanan publik pemerintahan desa tersebut di atas? Tentu saja kita harus mengidentifikasi urusan atau kewenangan yang dimiliki pemerintah desa sesuai dengan amanat UU Nomor 6 tahun 2014. Disamping itu, juga perlu mengidentifikasi kondisi empiris dan current conditions terkait dengan jenis, jumlah dan lingkup pelayanan publik pemerntah desa yang selama ini dilakukan. Dari hasil identifikasi tersebut, akan ditemukan jenis, jumlah dan lingkup pelayanan publik pemerintahan desa yang konstekstual, yang pada akhirnya akan menjadi pola/ model pelayanan publik pemerintahan desa yang seluruhnya menjadi totolitas sepenuhnya bagi desa. Pola/model ini paling tidak akan dapat menjadi rumusan secara umum terkait dengan pelayanan publik desa yang bersifat administratif.

Sesuai dengan Pasal 18 UU No. 6 Tahun 2014 disebutkan bahwa kewenangan desa meliputi kewenangan di bidang penyelenggaraan Pemerintahan Desa, pelaksanaan Pembangunan Desa, pembinaan kemasyarakatan Desa, dan pemberdayaan masyarakat Desa berdasarkan prakarsa masyarakat, hak asal usul, dan adat istiadat Desa.

Selanjutnya dalam Pasal 19, secara lebih eksplisit disebutkan bahwa kewenangan Desa meliputi: (a) kewenangan berdasarkan hak asal usul; (b) kewenangan lokal berskala Desa; (c) kewenangan yang ditugaskan oleh Pemerintah, Pemerintah Daerah Provinsi, atau Pemerintah Daerah Kabupaten/Kota; dan (d) kewenangan lain yang ditugaskan oleh Pemerintah, Pemerintah Daerah Provinsi, atau Pemerintah Daerah Kabupaten/Kota sesuai dengan ketentuan peraturan perundangundangan.

Berdasarkan kewenangan desa tersebut di atas, sesuai dengan Pasal 26, Kepala Desa berwenang: (a) memimpin penyelenggaraan Pemerintahan Desa; (b) mengangkat dan memberhentikan perangkat Desa; (c) memegang kekuasaan pengelolaan Keuangan dan Aset Desa; (d) menetapkan Peraturan Desa; (e) menetapkan Anggaran Pendapatan dan Belanja Desa; (f) membina kehidupan masyarakat Desa; (g) membina ketenteraman dan ketertiban masyarakat Desa; (h) membina dan meningkatkan perekonomian Desa serta mengintegrasikannya agar mencapai perekonomian skala produktif untuk sebesar-besarnya kemakmuran masyarakat Desa; (i) mengembangkan sumber pendapatan Desa; (j) mengusulkan dan menerima pelimpahan sebagian kekayaan negara guna meningkatkan kesejahteraan masyarakat Desa; (k) mengembangkan kehidupan sosial budaya masyarakat Desa; (l) memanfaatkan teknologi tepat guna; (m) mengoordinasikan Pembangunan Desa secara partisipatif; (n) mewakili Desa di dalam dan di luar pengadilan atau menunjuk kuasa hukum untuk mewakilinya sesuai dengan ketentuan peraturan perundang-undangan; dan (o) melaksanakan wewenang lain yang sesuai dengan ketentuan peraturan perundang-undangan.

Atas dasar wewenang Kepala Desa tersebut di atas, dalam melaksanakan tugasnya, Kepala Desa berkewajiban: (a) memegang teguh dan mengamalkan Pancasila, melaksanakan UndangUndang Dasar Negara Republik Indonesia Tahun 1945, serta mempertahankan dan memelihara keutuhan Negara Kesatuan Republik Indonesia, dan Bhinneka Tunggal Ika; (b) meningkatkan kesejahteraan masyarakat Desa; (c) memelihara ketenteraman dan ketertiban masyarakat Desa; 
(d) menaati dan menegakkan peraturan perundang-undangan; (e) melaksanakan kehidupan demokrasi dan berkeadilan gender; (f) melaksanakan prinsip tata Pemerintahan Desa yang akuntabel, transparan, profesional, efektif dan efisien, bersih, serta bebas dari kolusi, korupsi, dan nepotisme; (g) menjalin kerja sama dan koordinasi dengan seluruh pemangku kepentingan di Desa; (h) menyelenggarakan administrasi Pemerintahan Desa yang baik; (i) mengelola Keuangan dan Aset Desa; (j) melaksanakan urusan pemerintahan yang menjadi kewenangan Desa; (k) menyelesaikan perselisihan masyarakat di Desa; (l) mengembangkan perekonomian masyarakat Desa; (m) membina dan melestarikan nilai sosial budaya masyarakat Desa; (n) memberdayakan masyarakat dan lembaga kemasyarakatan di Desa; (o) mengembangkan potensi sumber daya alam dan melestarikan lingkungan hidup; dan (p) memberikan informasi kepada masyarakat Desa.

Selanjutnya bagaimana perspektif pelayanan publik desa kedepan, yang memiliki berbagai karakteristik yang berbeda-beda. Dari aspek tipologi ada desa adat, yang juga memiliki berbagai bentuk yang juga berbeda-beda. Sedangkan dari aspek geografis, karakteristik desa dapat dibedakan menjadi desa industri, desa maritim, desa pertanian dan desa wisata. Berbagai karakteristik desa tersebut akan sangat berpengaruh terhadap pola/model pelayanan publik desa masing-masing. Contoh untuk desa pertanian kebutuhan pelayanan publik diluar kebutuhan dasar dan administratif, tentu akan lebih diutamakan pada pelayanan penyuluhan, pengadaan bibit, pengadaan pupuk, pengolahan hasil panen serta pemasaran hasil panen. Begitupun juga akan berlaku untuk desa-desa dengan karakteristik yang berbeda, baik berdasarkan tipologi maupun didasarkan pada karakteristik berdasarkan geografis.

Terkait dengan model pelayanan publik, menurut Titin Rohayatin dan Agustina Setiawan dalam Jurnal Ilmu Politik dan Komunikasi, Universitas Komputer Indonesia (UNIKOM) Volume V No. 1/Juni 2015 terdapat 3 model pelayanan publik, yaitu:

(1) Model I : Model Sistem Terpisah/Terpencar. Beberapa Dinas Dapat memberikan pelayanan langsung kepada masyarakat dengan model sebagai berikut :

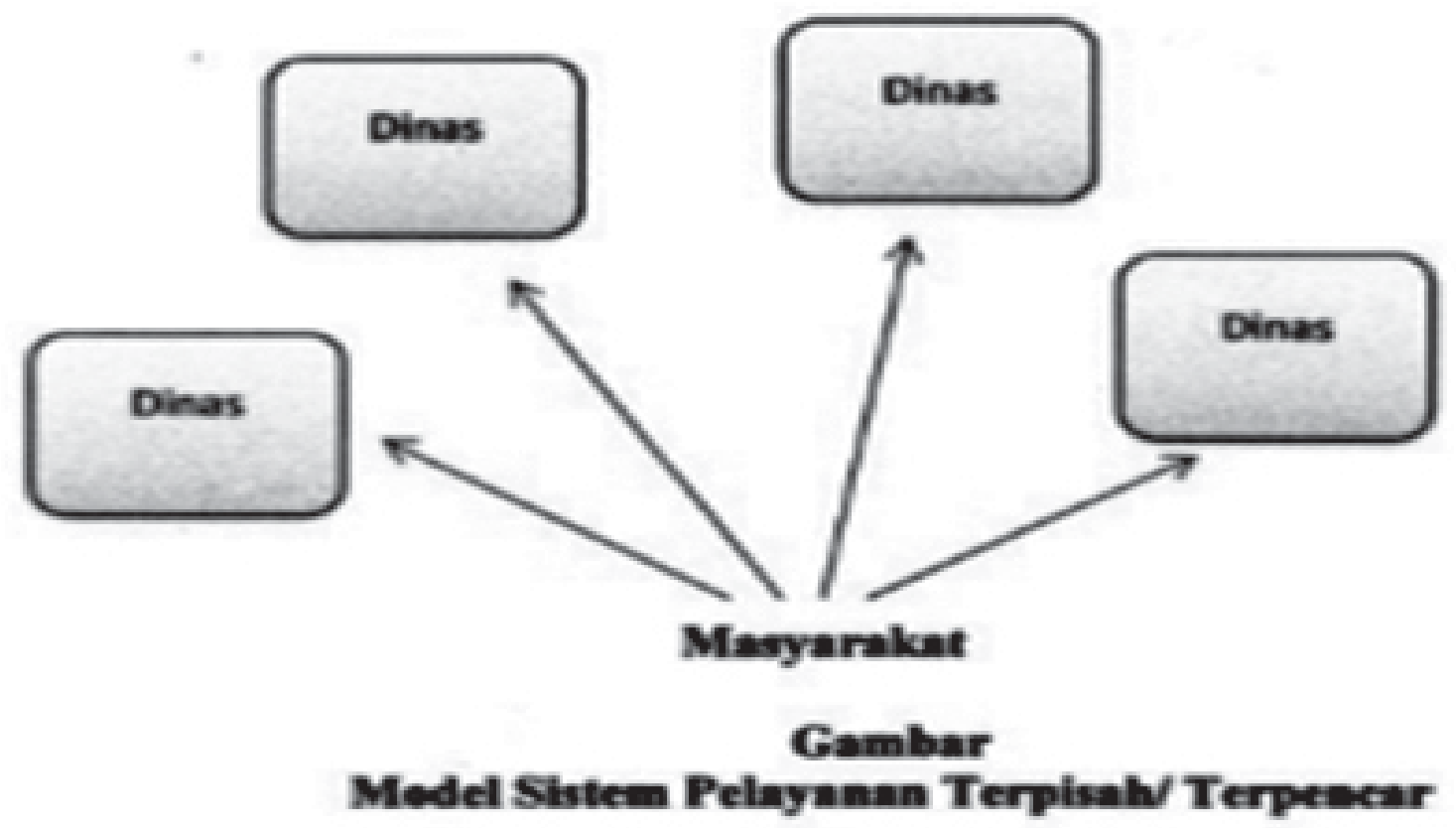


(2) Model II : Sistem Pelayanan Satu Atap. Unit kerja dapat mengumpulkan berkas, penyelesaian perizinan tetap ada di dinas masing-masing, model ini dapat dilihat pada gambar berikut:

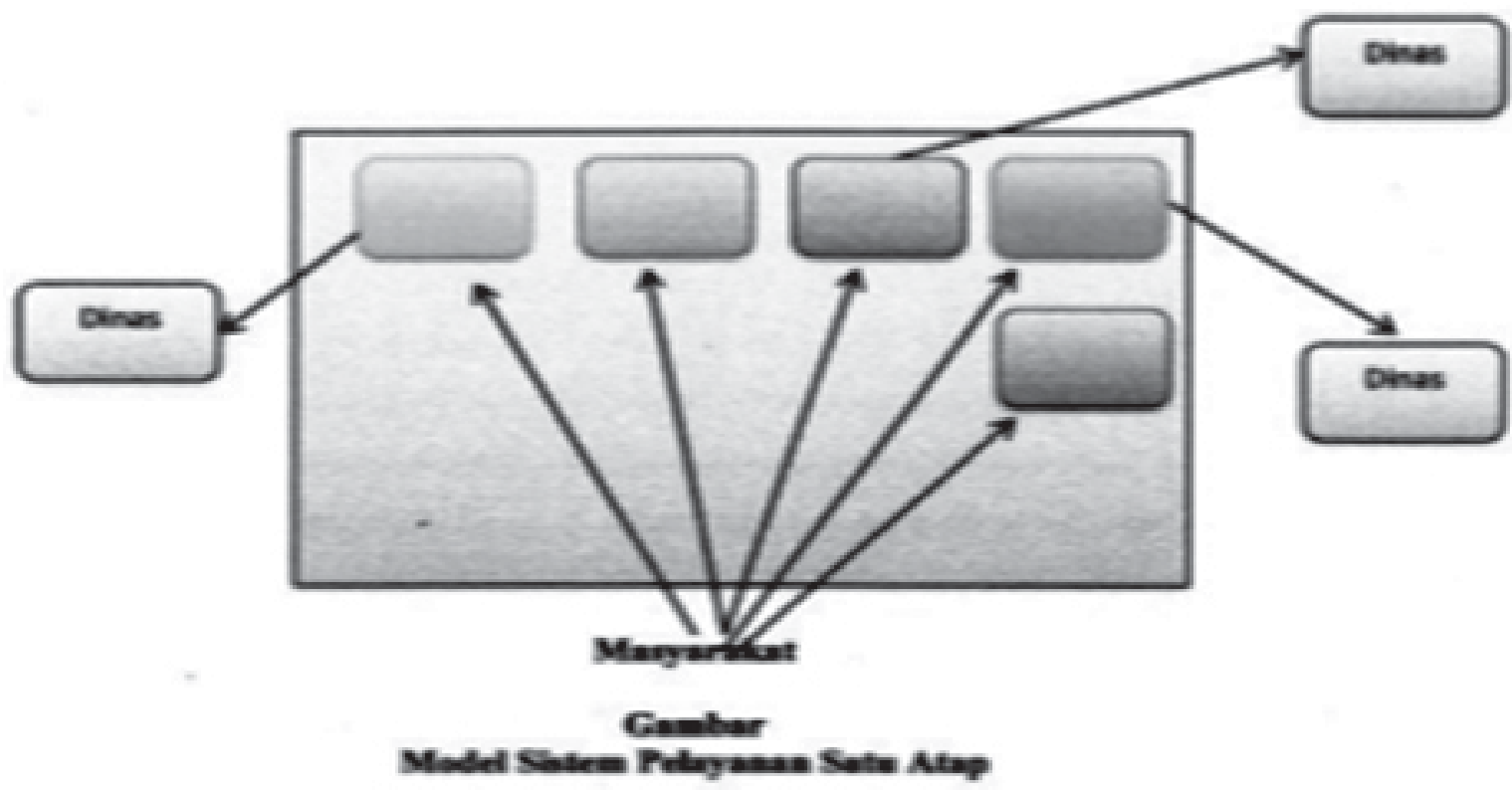

(3) Model III: Sistem Pelayanan Satu Pintu (One Stop Service/ OSS). Sistem pelayanan Satu Pintu sering dikenal dengan One stop service atau sering disingkat OSS, dan jenis pelayanan one stop service atau OSS ini ada cabang online, model ini dapat dilihat pada gambar berikut:

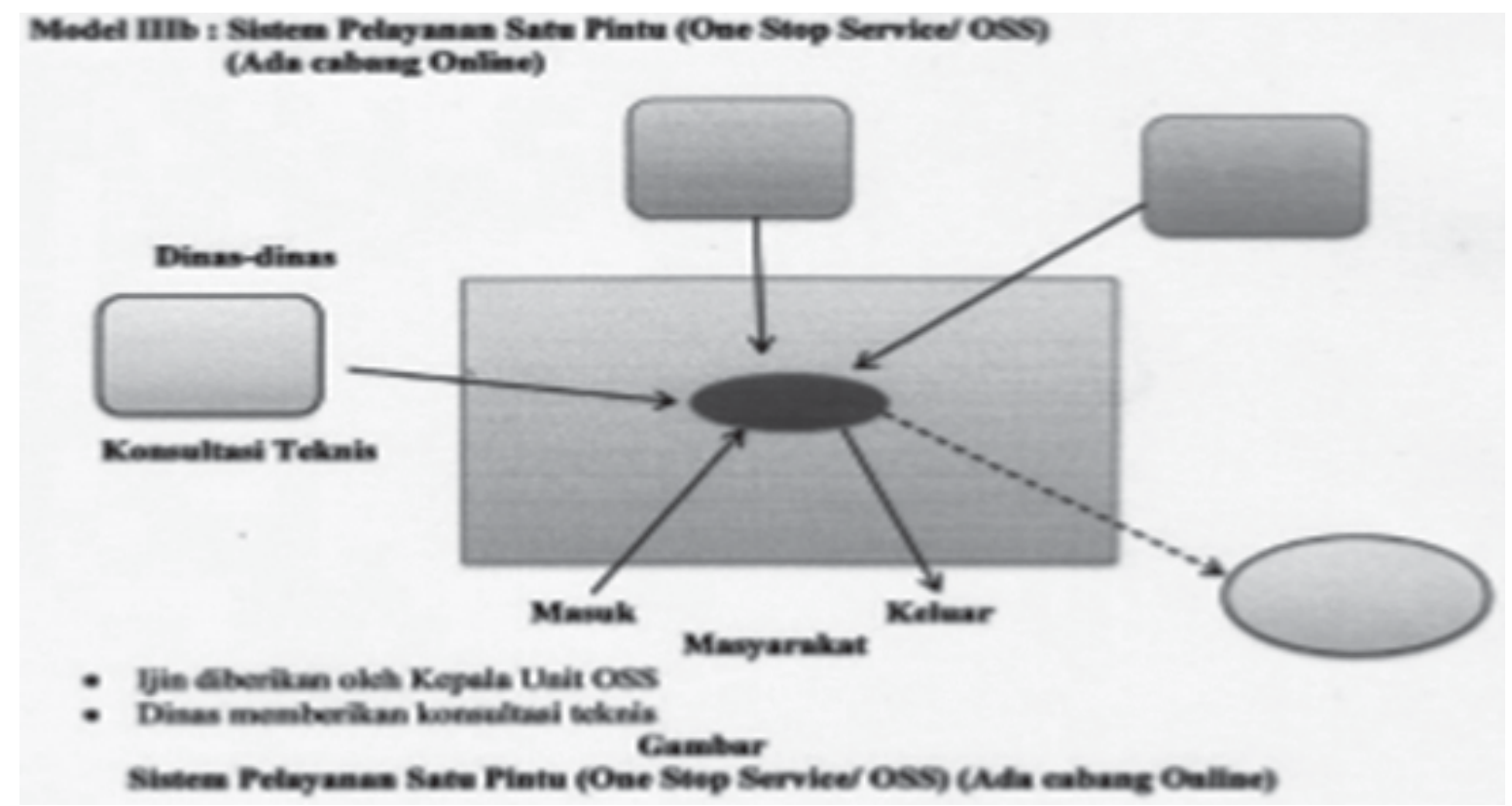

Untuk membangun model pelayanan publik desa yang kontekstual, maka harus dimulai dari kewenangan desa serta melihat kembali pelayanan empiris saat ini. Frame Work untuk medesain pola/model pelayanan publik pemerintahan desa dapat dilihat pada gambar 3 sebagai berikut: 


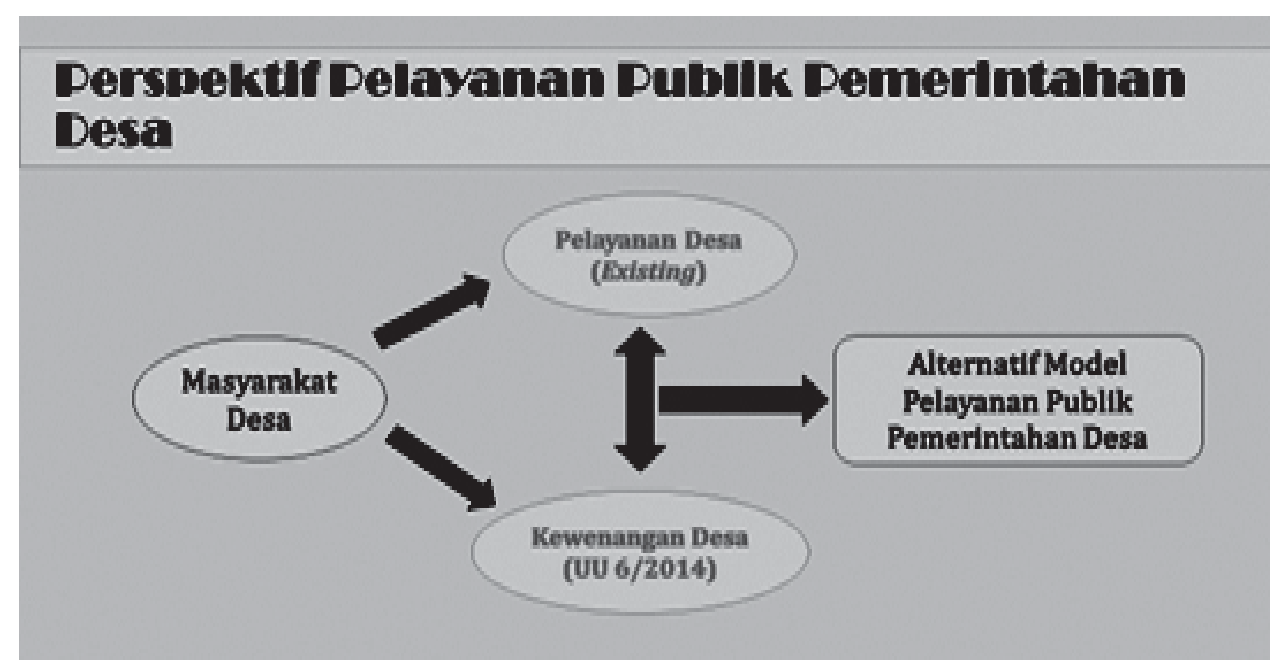

Gambar 3.

Kerangka Pemodelan Pelayanan Publik Desa

Berdasarkan framework tersebut di atas, maka desain model pelayanan publik desa didasarkan pada kondisi existing sebagaimana telah dihasilkan dari beberapa studi tentang pelayanan publik desa, kewenangan desa dan model pelayanan publik yang telah dikembangkan. Pelayanan publik desa existing secara umum mencakup: (1) Pelayanan bersifat Pengantar, mencakup : (a) KTP (baru dan Perpanjang); (b) KK (baru dan perubahan); (c) SKDU (Baru dan Perpanjang); (d) Domisili Haji; (e) Surat Pengantar SKCK; (f) Surat Pindah; (g) SKTM; (h) Izin Keramaian; (i) Surat Pengantar Nikah (NA); (2) Pelayanan Selesai di desa: (a) Surat keterangan Kelahiran; dan (2) Surat keterangan Kematian.

Sedangkan kewenangan desa meliputi: a. kewenangan berdasarkan hak asal usul; b. kewenangan lokal berskala Desa; c. kewenangan yang ditugaskan oleh Pemerintah, Pemerintah Daerah Provinsi, atau Pemerintah Daerah Kabupaten/Kota; dan d. kewenangan lain yang ditugaskan oleh Pemerintah, Pemerintah Daerah Provinsi, atau Pemerintah Daerah Kabupaten/Kota sesuai dengan ketentuan peraturan perundang-undangan. Adapun model pelayanan publik mencakup: (1) Model Sistem Terpisah/ Terpencar; (2) Model satu atap; dan (3) Model satu pintu (OSS). Berdasarkan hal tersebut, maka desain model pelayanan publik pemerintahan desa kedepan dapat dilihat pada gambar 4 sebagai berikut:

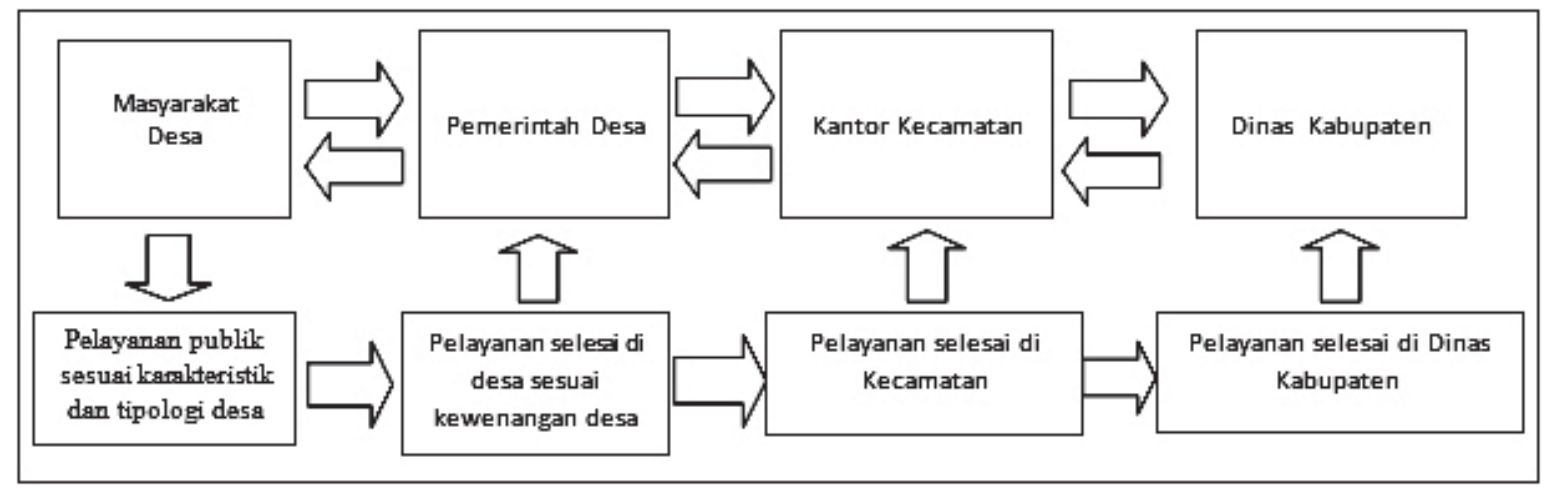

Sumber : Kewenangan desa UU 6/2014 dan pelayanan desa existing, diolah.

Gambar 4.

Desain Model Pelayanan Publik Pemerintahan Desa 
Dari model pelayanan publik pemerintahan desa tersebut di atas, maka selanjutnya perlu disusun bisnis proses pelayanan publik desa baik untuk pelayanan publik yang berakhir di Desa, Kantor Kecamatan, maupun pelayanan publik yang berakhir di Dinas Kabupaten. Pada gambar 5 berikut ini adalah Bisnis proses pelayanan publik pemerintahan desa terintegrasi dari Desa, Kecamatan dan Dinas Kabupaten.

\begin{tabular}{|l|l|l|}
\hline Dinas Kabupaten & Kantor Kecamatan & Proses \\
\hline Pemerintah Desa & &
\end{tabular}

Gambar 5.

Bisnis Proses Pelayanan Publik Pemerintahan Desa Terintegrasi

Jika dicermati bisnis proses tersebut di atas, maka sesungguhnya pelayanan publik desa merupakan bagian yang tak terpisahkan dari sistem pelayanan publik Kecamatan dan Pemerintah Kabupaten. Namun demikian, seiring dengan kewenangan yang dimiliki maka pemerintahan desa sudah selayaknya dapat membuat model pelayanan publiknya yang benar-benar mandiri dan selesai di pemerintahan desa masing-masing. Atau dengan kata lain, pemerintahan desa harus segera menyusun manajemen pelayanan publik desa. Mulai dari menentukan jenis pelayanan publik apa saja yang harus dilakukan sesuai dengan kewenangan yang dimiliki desa berdasarkan UU Nomor 6 tahun 2014. Selanjutnya menentukan lingkupnya, pelayanan apa saja yang menjadi kewenangan dan selesai di tingkat pemerintahan desa, pelayanan apa yang selesai di Kantor Kecamatan, serta pelayanan apa saja yang selesai di Dinas Kabupaten. Untuk jenis pelayanan publik yang menjadi kewenangan mutlak pemerintahan desa dan selesai di tingkat desa, maka dapat disusun bisnis proses pelayanan publik internal desa sebagaimana dapat dilihat pada gambar 6 sebagai berikut.

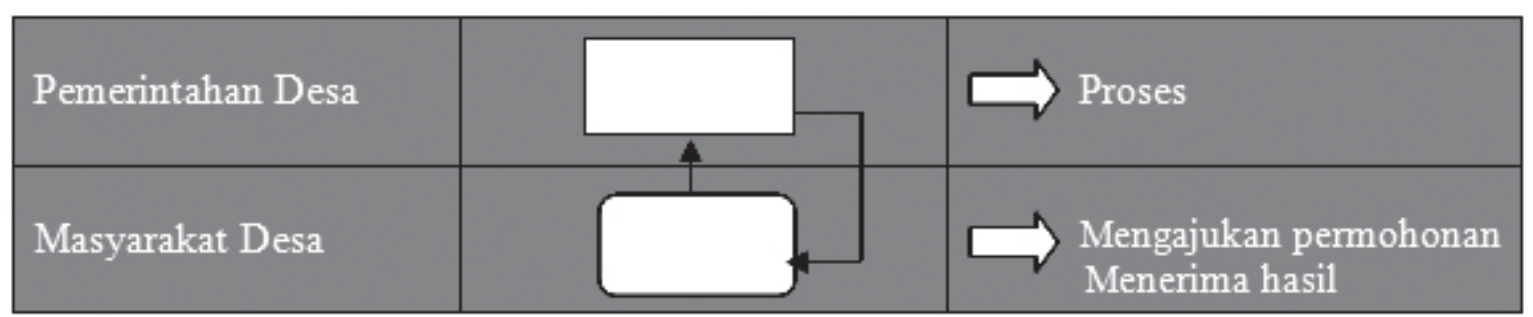

Gambar 6.

Bisnis Proses Pelayanan Publik Internal Pemerintahan Desa

Berdasarkan peta bisnis proses (business process mapping) jenis dan lingkup pelayanan publik pemerintahan desa, maka perlu disusun Standar Pelayanan (SP) dan Maklumat Pelayanan serta disusun Standar Operasional Prosedur (SOP) untuk setiap jenis pelayanan. 
Beberapa hal yang harus dipersiapkan oleh pemerintahan desa dalam menjalankan fungsi pelayanan publik. Merujuk pada UU Pelayanan Publik, setidaknya ada empat hal yang harus dilakukan oleh pemerintah desa, meliputi: (1) Menyusun dan menetapkan standard pelayanan; (2) Menyusun, menetapkan, dan mempublikasikan maklumat pelayanan; (3) Menempatkan pelaksana yang kompeten; dan (4) Menyediakan sarana, prasarana, dan/atau fasilitas pelayanan publik yang mendukung terciptanya iklim pelayanan yang memadai.

Selanjutnya dalam ranah pelayanan administrasi di tingkat desa, keempat hal di atas diselenggarakan oleh pemerintah desa untuk melayani urusan administrasi desa, meliputi: (1) administrasi Umum; (2) administrasi Penduduk; (3) administrasi Keuangan; (4) administrasi Pembangunan; (5) administrasi Badan Permusyawaratan Desa (BPD), dan (6) administrasi lainnya.

\section{E. PENUTUP}

Bagian akhir dari tulisan ini merupakan saripati dari hasil studi tentang model pelayanan publik desa pasca diberlakukannya Undang-Undang Nomor 6 Tahun 2014 tentang Desa, yang mencakup kesimpulan dan rekomendasi.

\section{Kesimpulan:}

(1) Pelayanan publik desa berdasarkan jenis dan jumlahnya masih berbeda-beda. Disamping itu, klasifikasinya juga masih berbeda-beda, ada yang klasifikasinya surat dengan segala jenisnya, ada juga surat pengantar dengan segala jenisnya.

(2) Secara umum pelayanan publik desa berupa pengantar atau rekomendasi saja dan penyelesian pelayanannya berada di Kantor Kecamatan atau bahkan di Dinas Teknis Pemerintah Kabupaten/ Kota.

(3) Pelayanan publik desa secara umum dapat dikelompokkan menjadi 3 (tiga), yaitu: (1) surat pengantar; (2) layanan kependudukan; dan (3) pemberdayaan masyarakat desa;

(4) Model pelayanan publik desa yang dapat dikembangkan adalah model terpencar, mengingat pelayanan publik desa merupakan bagian yang tak terpisahkan dari sistem pelayanan publik Kecamatan dan Pemerintah Kabupaten/Kota. Hanya sebagian kecil saja pelayanan publik desa yang betul-betul dapat diselesaikan didesa (berupa surat pengantar), selebihnya diselesaikan di tingkat Kecamatan dan bahkan di Dinas-Dinas Teknis Kabupaten/Kota.

\section{Rekomendasi :}

(1) Seiring dengan kewenangan yang dimiliki maka pemerintahan desa sudah selayaknya dapat membuat model pelayanan publiknya yang benar-benar mandiri dan selesai di pemerintahan desa masing-masing.

(2) Pemerintahan desa harus segera menyusun manajemen pelayanan publik desa termasuk standarstandar pelayanan dan SOP-nya.

(3) Menentukan jenis pelayanan publik apa saja yang harus dilakukan sesuai dengan kewenangan yang dimiliki desa berdasarkan UU Nomor 6 tahun 2014. Selanjutnya menentukan lingkupnya, pelayanan apa saja yang menjadi kewenangan dan selesai di tingkat pemerintahan desa, pelayanan apa yang selesai di Kantor Kecamatan, serta pelayanan apa saja yang selesai di Dinas Kabupaten.

(4) Terkait dengan percepatan penguatan kapasitas desa dalam rangka meningkatkan kualitas pelayanan publik desa, dapat dilakukan melalui: (1) training perubahan mindset dan cultur set aparat desa untuk melayani warganya; (2) perubahan budaya kerja; (3) Bimtek penyusunan 
visi dan misi pelayanan publik desa, penyusunan Standar Pelayanan(SP) dan Standar Operasional Prosedur (SOP); (4) pelaksanaan survey kepuasan masyarakat desa dan pengelolaan pengaduan; (5) monitoring dan evaluasi pelaksanaan SP dan SOP.

\section{DAFTAR PUSTAKA}

Afrizal Ahmad, Arizki. (2014). Kinerja Pemerintahan Desa Sebagai Penyedia Pelayanan Publik di Desa Wringinpitu Kecamatan Mojowarno Kabupaten Jombang, Jurnal Pendidikan Kewarganegaraan, Universitas Negeri Malang, 1(1). Online: http://jurnal-online.um.ac.id/ data/artikel/artikelA66FE1A33C9392F1D5F88DF81A6BC30B.pdf diakses tanggal 16 Februari 2017.

Agustina, Yeni. (2015). Peran Kepala Desa Dalam Pelayanan Publik Di Kantor Desa Sukoulyo Kecamatan Long Iram Kabupaten Kutai Barat, Jurnal Administrasi Negara, Fisip UNMUL, 3 (4), hal. 964-975. Online: file://D:/Jurnal\%20\%20burneo\%20review/Ejournal\%20yeni_2\%20(08-12-15-06-15-46).pdf diakses tanggal 23 Februari 2017.

Boediono. (1993). Pelayanan Prima Perpajakan. Jakarta: Rineka Cipta.

Evan, James R and Lindsay. (1997). The Management and Control of Quality, West Publishing Company, United State.

Heden Higau, Clement Belly. (2015). Pelaksanaan Administrasi Pemerintahan Desa Dalam Meningkatkan Pelayanan Masyarakat di Desa Matalibaq Kecamatan Long Hubung Kabupaten Mahakam Ulu, Jurnal Ilmu Pemerintahan, Fisip UNMUL, 3 (3), hal. 14481459. Online: file://D:/Jurnal\%20\%20burneo\%20review/Jurnal\%20(10-12-15-10-3757).Pdf diakses tanggal 20 Februari 2017.

Jaenuri. (1999). Peranan Kantor Pelayanan Pajak Pratama (KPPP) Kabupaten Pati Dalam Meningkatkan Kesadaran Masyarakat Membayar Pajak, Jurnal Ilmiah PPKN, IKIP Veteran Semarang, 2 (1), hal. 88-100. Online: http//e-journal.ikip-veteran.ac.id/index.php/democratia/ article/download/221/230. pdf diakses tanggal 20 Februari 2017.

Keputusan MenPAN No 63 tahun 2003 tentang Pedoman Umum Penyelenggaraan Pelayanan Publik.

Lembaga Administrasi Negara RI. (2006). Strategi Peningkatan Kualitas Pelayanan Publik. Jakarta: LAN RI

\section{LAN RI.}

. (2013) Simplifikasi Administrasi Pelayanan Perizinan Dunia Usaha. Jakarta:

. (2015). Pelayanan Publik Desa, Bagaimana Kualitas dan Inovasinya. Bahan Paparan Diskusi Terbatas. Jakarta: LAN RI.

Lumbung Komunitas. (2014). Laporan Hasil Lokakarya Jenis-Jenis Pelayanan Publik Desa Temanggung dan Ngargomulyo. Muntilan, Magelang.

Ndraha. (2003). Kybernologi Ilmu Pemerintahan Baru 1. Jakarta: Rineka Cipta.

Novita Sari, Dewi. (2014). Persepsi Masyarakat Randukuning Terhadap KinerjaAparatur Pemerintah Desa, Jurnal Ilmiah, Universitas Veteran Semarang, 2 (1), November, hal. 77-89. Online: e-journal.ikip-veteran.ac.id/index.php/democratia/article/view/344. pdf diakses tanggal 14 Februari 2017. 
Peraturan Menteri Dalam Negeri Nomor 114 tahun 2014 Tentang Pedoman Pembangunan Desa. Peraturan Menteri Desa, PDT dan Transmigrasi Nomor 3 Tahun 2015 Tentang Pendampingan Desa.

Peraturan Pemerintah Nomor 96 Tahun 2012 tentang Pelaksanaan Undang-Undang Nomor 25 Tahun 2009 Tentang Pelayanan Publik.

Peraturan Pemerintah Nomor 43 Tahun 2014 tentang Peraturan Pelaksanaan Undang-Undang Nomor 6 Tahun 2014 Tentang Desa.

Peraturan Presiden Nomor 2 Tahun 2015 tentang Rencana Pembangunan Jangka Menengah Nasional (RPJMN) 2015-2019.

Publishing.

Setiawan Agustina, Rohayatin Titin.(2012). Pemodelan Kualitas Penyelenggaraan Pelayanan Publik Di Kantor Pelayanan Perizinan Terpadu (Kppt) Kota Cimahi, Jurnal Ilmu Politik dan Komunikasi, Universitas Komputer Indonesia (UNIKOM), 5 (1), Juni, hal. 91-105.

Suwarno, Joni. (2012). Kualitas Pelayanan Pemerintah Desa Teluk Kepayang, Kecamatan Kusan Hulu, Kabupaten Tanah Bumbu. Jurnal Ilmu Politik dan Pemerintahan Lokal, 1 (2).

Undang-Undang Nomor 25 Tahun 2009 tentang Pelayanan Publik.

Undang-Undang Nomor 6 Tahun 2014 tentang Desa.

Widodo, Joko. (2001). Membangun Birokrasi Berbasis Kinerja. Jakarta: Bayumedia. 